\title{
Business Educational Psychology: Knowledge Management in Organizations
}

\author{
Henrique Guilherme Scatolin \\ PUC-SP (Pontificate Catholic University of São Paulo); \\ Herminio Ometto University Center-Uniararas
}

(Araras/SP), São Paulo, Brazil

\author{
Zirlagem Martins Pereira Silva \\ Herminio Ometto University Center-Uniararas \\ (Araras/SP), São Paulo, Brazil
}

\begin{abstract}
This paper presents the reflections on the educational psychologist activity in the business organizations management regarding his role and how he should act in this context, in addition to exposing the evolution of these organizations until the present, as well as its apparent changes. The methodology used in this paper is based on the literature review. As a result, this paper highlights that the employees' educational training promotes the educational psychologist activity possibilities, both in the administration and in socio-educational projects implementation, including skill-building and training courses. Through the educational psychologist activities, business organizations assume the role of managers and facilitators in the knowledge construction, encouraging new forms of relationship. The educational psychologist creates a synergy between the managers and employees behavior, planning, evaluating, favoring, and promoting courses to meet the employees and the business organization needs. Therefore, this paper concludes that the educational psychologist activity in business organizations brings improvements in the employees' performance and internal communication, contributing to the talents maintenance and promoting the quality of life improvement.
\end{abstract}

Keywords: business educational psychology, organizational learning, knowledge management

\section{Introduction}

For business organizations achieving its development successfully, it is necessary to invest in the intellectual capital training, finding means to adapt and develop with new technologies, thus investing in the continuous learning of its employees, in productive health of the business organization, and in its position in the globalized and competitive market, where the information updating and recycling requirements are increasingly necessary.

According to Costa (2009, p. 35), "One of the main difficulties of business organizations is the organizational knowledge loss". Taking into consideration that learning is a differentiator for organizations that develop new knowledge; knowledge management also arouse as a differential with the human learning

\footnotetext{
Henrique Guilherme Scatolin, Graduated in Psychology from the Methodist University of Piracicaba (UNIMEP), Master's Degree in Psychology from PUC-SP, and Doctorate in Clinical Psychology from PUC-SP. Faculty member of Herminio Ometto University Center-Uniararas (Araras/SP). Research advisor in the educational and organizational area of this university. The contact e-mail is henriquescatolin@hotmail.com.

Zirlagem Martins Pereira Silva, Graduated in Pedagogy from Montes State University-UNIMONTES (MG), postgraduate student in Clinical and Institutional Educational Psychology at Herminio Ometto University Center-Uniararas (Araras/SP). The contact email is lanneguerra@bol.com.br.
} 
possibilities. In this sense, the educational psychologist works with the knowledge built by the individual in the business organization, because he is the professional skilled to deal with the learning, ensuring the knowledge integration and dissemination, in addition to qualifying and preparing the employees to perform their tasks, seeking ways to invest in learning, thinking of new attitudes regarding the intelligences, the evaluation forms and the development of the employees skills and competencies. The perception that the development of a business organization is read through individual competencies dynamics and values established in the society are essential. Therefore, the educational psychologist must create an environment that enables the sharing and development of skills and abilities, aiming to succeed in the teamwork.

For Chiavenato (2007), a team of employees working harmoniously is important for the development of an organization, but currently there is still little investment by business organization for skill-building, hearing their needs, and supporting the employees.

According to Fleury and Oliveira Júnior (2002), human capital, as an element holder of organizational learning, becomes the differential and with it the organizations increase need for learning to develop new knowledge.

Thus, this work proposes to show and expand the knowledge on the educational psychologist role in the knowledge management of business organizations. The need for this professional activity is latent within the organization. The methodology applied in this study is based on bibliographic researches whose main theorists are Idalberto Chiavenato, Marília Maia Costa, and Nadia Bossa. Finally, I highlight that this work was approved by the Ethics Committee in Research and Scientific Merit of Uniararas on May 15, 2012, through the protocol No. 188/2012.

\section{The Evolution of Business Organizations and the Need for the Educational Psychologist Activity}

According to Chiavenato (2007), from the First Industrial Revolution, and with the industries emergence, the first changes in the business organizations behavior and management were noticed. The artisanal work was replaced by machines, large industries were emerging and, with them, the need to increase manpower, the profit, the products, and services quality. The first partnerships/mergers and the increased competition appear accelerating the growth and the products low cost, which allowed the competitiveness and the market expansion. With the beginning of workshops implementation, the technologies incorporation, and the tasks division among the more and less qualified professionals, organizations began to require more and more from their employees-The workers began to work for longer hours, in terrible conditions and without benefits. The owners began to face problems with the working class arising, then, the labor laws to protect workers.

According to Morgan (1996), with the industries emergence, the owners began to worry about the business organizations management. New ideas, methods, specializations and a department to manage the employees' professional life emerged - the "Human Resources"-which would have the function of selecting workers according to their skills and with the business organization needs, as well as to prepare and train employees to produce more and better, meeting the organization expectations and planning. This department structures and manages positions, benefits and functions, and also organizes skill-building courses, trainings, socio-educational projects development, as well as the employees' performance evaluation.

According to Angeloni (2003), within a business organization, each professional has a job or position defined, with specific sphere of competence, with official duties, strictly specific and delimited assignments. 
However, the employee behavior not always occurs within the expected, and unintended consequences may occur, which may lead to inefficiency, to services and products production and quality decrease, making the employee to be more concerned with rules and regulations than with the own work; with the excessive formalism and the tendency to document and formalize everything, the authority excess, privileges and the power arise, causing the performance loss. The employee leaves aside the duties inherent to the position, feeling threatened; he is not trained and does not grow with the business organization, as part of the resistance to changes, because these are seen as a threat to the employee position and stability. The issue of how to deal with external influences and with employees, how to work with motivation, incentives, dynamics, trainings, internal communication, and leadership development, how to encourage spontaneity and the humanization process, and how to deal with tasks, structures, people and technologies in the work environment arise. In this sense, Chiavenato (2007, p. 19) states that "The efficiency of an organization is much more than the sum of its employees efficiency".

\section{The Educational Psychologist Activity in Business Organizations}

According to Costa (2009, p. 14), "to perform as an educational psychologist in business organizations is a great challenge, since most of the directors, managers and employees do not know how to define what is this professional function”. But, after all, what does an educational psychologist do in a business organization?

In business organizations, the educational psychologist performs in the socio-educational projects implementation, organizing trainings, skill-building courses, and employees' performance evaluation, in addition to performing in the interrelationship between all with the teaching-learning process and with the supervision of difficulties in the relationship between sectors.

For Lopes (2007), the educational psychologist seeks the employees' valorization, promoting interventions to observe how they react in various moments at work and how they deal with frustrations and errors. The educational psychologist organizes lectures, workshops, institutional videos, debates, dynamics and work simulations, strategically promoting the meeting of people and sectors, organizing environments suitable to receive and follow-up the adaptation of new employees, mediating information, introducing colleagues, sectors and tasks.

In this sense, Costs (2009) states that the educational psychologist carries out field work, internal researches of labor relations development, induces the organization to produce more and better, disseminates among employees the mission, vision, values and strategies knowledge of the business organization, observes its profile an focus, and teaches them to understand the dynamics, operations, and where the organization is heading.

Within business organizations, the educational psychologist performs with the human resources, interacting with other professionals, such as neurologists, psychologists and speech therapists, a relation that helps him to understand the origin of the learning difficulties and disorders presented by employees, in addition to assisting him in the difficulties and deficits monitoring. In this sense, Costa (2011, p. 23) points out that "This expert must guide and not label, look at the whole and not to the parts of the whole".

\section{Educational Psychologist Activity in the Organization and the Implementation of Socio-Educational Projects, Trainings, and Skill-Building Courses}

Costa (2009) states that, to perform in the organization and in the implementation of socio-educational projects, trainings and skill-building courses in business organizations, the educational psychologist needs to be 
updated, organized and understand education, in addition to knowing how to organize courses worksheets and syllabus, since, without organization and monitoring, the educational psychologist work gets lost. It is necessary to know recognized entities and courses, to know how to listen, to have a refined hearing, good communication and good knowledge of the organization, its departments and managers.

The socio-educational projects should be geared to the business organization development proposal, aiming to enhance the company intellectual capital, adding values to people, motivating and valuing the employees to contribute with the goals and targets set in the business organization development plan.

According to Lopes (2007), the socio-educational projects implementation adds value feeling in the mission, vision, values and strategies already established in the business organization (or in the formation of values or rescue of others), improving human relations at work, providing opportunities for the exchange of experiences among employees, stimulating and realizing the employees behavior regarding the business organization.

For following-up the market launch of new products, services, and technologies, the business organization needs to invest in its employees, developing skill-building, training, and socio-educational programs. The training goal, within the social-educational projects proposal, is to lead the employees to develop new skills and specific abilities in certain functions, aiming at increasing their productivity and development, focusing on the business organization and employees progress regarding the positions, career, and profession (Costa, 2009).

The organization of socio-educational, training and skill-building projects for the business organization human development should be connected to scholarships in partner colleges, as well as these trainings can be internal and external, and the skill-building courses can be inserted in trainees and interns programs (Costa, 2009, p. 34).

The ideal in the trainings organization and implementation, such as skill-building, is to prepare a flowchart of the entire courses/trainings and projects program that will be offered by the business organization, specifying the courses/activity areas and the target audience, as well as the activities schedule and objectives to be achieved in each area. The socio-educational projects can be prepared according to the business organization demand and need and, regarding this, it is essential to give priority to the most urgent skill-building curses, trainings and socio-educational projects and its duration must be according to the projects. All employees can participate in the projects and courses since such course is linked to the activities carried out by them, and his immediate superior is in mutual agreement. The educational psychologist must be aware of the fear that some employees have to ask and demonstrate that they do not know to better guide them. So, it is the educational psychologist responsibility to organize skill-building courses on heath, job performance, time management, customer service, as well as instrumental Portuguese, among others. And for the realization of educational projects, trainings and skill-building courses, it is important that the event time is not the same of the working hours. So there are no conflicts, it is important to establish rules for the employees' participation.

According to Costa (2009), after the skill-building courses, trainings, and socio-educational projects completion, it is necessary to make an evaluation comparing the before and after, talk to the employee about the skill-building, training and social-educational project carried out quality, and how was his exploitation. In addition, it is necessary to request the employee immediate superior to develop a report with the improvements observed after the course, training or socio-educational project carried out, its importance to the work, if it improved his performance area, and if he recommends the course, training and project to others. All this information assists the educational psychologist in shaping the business organization and its employees' profile, 
since the educational psychologist deals with a variety of behaviors. From this, an educational culture should be created within the organization, showing that this is concerned in promoting socio-educational projects, skill-building courses and trainings to develop and recover values, improve services and generate opportunities to its employees.

\section{The Educational Psychologist and the Employees Performance Evaluation}

The performance evaluation is a necessary task, because it is valid to monitor the employees' development regarding their functions. They are the business organization talents and co-responsible by their success. For the performance evaluation, it is necessary that the educational psychologist knows what each function needs and what are its requirements and skills. It is necessary to draw a parallel between what the function/position needs and what is offered by the employee, creating an action plan regarding the observed competencies.

The educational psychologist should create, jointly with the human resources department and the business organization directors, an assessment questionnaire, inventory or behavioral survey to be replied by the involved persons, and start a mapping intervening in relation to the deficiencies found in each employee, focusing on the action plan in the area in which the employee needs to improve. It is important that each employee knows why he is being evaluated, as well as the organization reasons and objectives (Lopes, 2007).

Through the performance evaluation process, the educational psychologist details the profiles, positions and skills of the business organization employees and, similarly, defines the proactive, flexible, communicative, creative and organized employees. With these profiles defined, it is possible to organize skill-building courses, trainings and socio-educational projects to meet the employees' real needs aiming at the success and quality in the functions performance.

For Costa (2009), the educational psychologist needs to respect the business organization in which he is part of, always acting with ethics and seeking to enhance the activities developed there, since it is up to him to provide the business organization employees with the access to knowledge, raise their commitment and value the knowledge construction, in addition to raising the employee professional level and, consequently, the performance effectiveness of his activities within the organization.

The human capital is truly the know-know holder in the business organization. Among the various aspects presented by Costa, it is worth highlighting that,

Investing in the human being is not only giving him a place to work and receiving a salary; it is to make him feel worthy, work for the trust and respect that he feels for the business organization, and receive what seems fair to him for what the business organization provides him as an employee, collaborator and citizen. (Costa, 2009, p. 57)

The educational psychologist is an allied of the business organization, because he acts in a humanized manner, seeking the growth and potential of its most important capital: the employee. Therefore, he is responsible for training proactive, flexible, communicative, creative, organized and focused on results employees.

\section{Final Considerations}

According to Bossa (2007), the educational psychology is an interdisciplinary knowledge field which study object is the human learning. In this sense, the educational psychologist activity in the organizations knowledge management emerges as the main source of competitive advantage for the teaching-learning process development, adding quality, and competence to human resources. 
The educational psychologist activity makes the business organizations to assume a role of knowledge and intellectual capital managers as its most important asset and, in this sense, the educational psychologist acts as a facilitator in the knowledge construction and sharing, encouraging the relationships forms and creating synergy between the managers and employees behavior, planning and evaluating the employees performance, learning and development. The educational psychologist favors, proposes, and coordinates updating courses that meet the organization needs, in addition to establishing the technical and methodological principles that allow the didactic monitoring of socio-educational projects, skill-building courses, training and development, and also for continually accessing the employees performance.

The perspective of this paper is that both directors and managers of business organizations see the educational psychologist as the professional skilled to act for the knowledge management, which they can count on the full potential of this professional to act in their organization, realizing the employees education is essential and an integral part of the organization.

In summary, the educational psychologist activity in the business organization improves the employees' performance and internal communication, contributing to the talents maintenance, identification of individual and interpersonal relationship problems among employees, encouraging the employees quality of life improvement and the harmony between groups; spreading among employees the knowledge of the business organization mission, vision and values, as well as the hierarchy roles and levels. Therefore, in general, the educational psychologist is responsible for seeking, above all, the satisfaction and development of employees, as well as the business organization where he is inserted.

\section{References}

Angeloni, M. T. (2003). Knowledge organizations: Infrastructure, people and technologies. São Paulo: Saraiva. Barbosa, L. M. (2001). Educational psychology in the school institution scope. Curitiba: Expoente.

Bossa, N. A. (2007). Educational psychology in Brazil contributions from the practice (3rd ed.). Porto Alegre: Artmed.

Chiavenato, I. (2007). Administration: Theory, process and practice (4th ed.). Rio de Janeiro: Elsevier.

Costa, M. M. (2009). Business educational psychology. Rio de Janeiro: Wak Editora.

Fleury, M. T. L., \& Oliveira jr, M. M. (2002). People in the organization. São Paulo: Gente.

Lopes, I. (2007). Business educational psychology: Activity manners and contexts. Rio de Janeiro: Wak Editora.

Morgan, G. (1996). Organization images. São Paulo: Atlas.

Parolin, I. C. H. (2003). Self-esteem as a tool in the learning and teaching process. Aprender Virtual Magazine. São Paulo: September/October 2003. Retrieved from htpp://www.aprendervirtual.com.br

Pinto, A. V. (1993). Seven lessons on adult education (8th ed.). São Paulo: Cortez.

Rego, T. (1995). Vygotsky: A historical and cultural perspective of education (15th ed.). Petrópolis: Vozes. 